\title{
EXTENDED STORAGE OF SUDANGRASS SEEDS
}

\author{
MARIANA ZAMPAR TOLEDO ${ }^{1}$, CLÁUDIO CAVARIANI ${ }^{2}$, \\ JOÃO NAKAGAWA ${ }^{2}$ and ELZA ALVES CORREA ${ }^{2}$
}

${ }^{1}$ Unigran, Dourados, MS, Brasil, mariana.toledo@unigran.br

${ }_{2}^{2}$ Unesp,Botucatu, SP, Brasil, ccavariani@fca.unesp.br, secdamv@fca.unesp.br

3Unesp, Registro, SP, Brasil, alves_elza@hotmail.com

$\overline{\text { Revista Brasileira de Milho e Sorgo, v.12, n.3, p. 326-335, } 2013}$

\begin{abstract}
Sudangrass stands out for being tolerant to drought and saline stress. However, studies on production of seeds and post-harvest technologies are insufficient considering both the demand and potential of this crop. This study aimed to monitor physiological quality of sudangrass seeds stored under different environmental conditions for a period of 18 months. Sudangrass seeds were stored under four conditions (natural environment, dry chamber, frost free, freezer). Physiological quality was assessed before storage and then every semester until 18 months by germination and vigor tests. Variance tests were applied for statistical analysis and means were compared as a $4 \mathrm{x} 4$ factorial. Storage environments were compared by the Tukey test $(\mathrm{p} \leq 0.05)$ and storage time by regression analysis. Speed and percentage of seedling emergence are reduced after 15-month storage of sudangrass seeds whereas seed germination, seedling development and seed weight are preserved until 18 months. Storing seeds under natural environment decrease vigor faster than conservation in dry chamber, frost free and freezer, although seedling growth is higher in that condition compared to the others.
\end{abstract}

Key words: Sorghum sudanense; germination; conservation; physiological quality.

\section{ARMAZENAMENTO PROLONGADO DE SEMENTES DE SORGO-SUDÃO}

RESUMO - O sorgo-sudão se destaca por sua tolerância à seca e estresse salino. No entanto, estudos sobre produção de sementes e técnicas de pós-colheita são insuficientes considerando-se a demanda e o potencial desta cultura. Este estudo objetivou monitorar a qualidade fisiológica de sementes de sorgo-sudão armazenadas em diferentes condições ambientais por um período de 18 meses. As sementes de sorgo-sudão foram armazenadas sob quatro condições (ambiente natural, câmara seca, geladeira frost free e freezer). A qualidade fisiológica foi avaliada por testes de germinação e vigor antes e durante o armazenamento, semestralmente, até 18 meses. Os dados foram submetidos à análise de variância e analisados em esquema fatorial 4 x 4, com médias de ambientes comparadas pelo teste de Tukey $(\mathrm{p} \leq 0,05)$ e períodos de armazenamento por análise de regressão. A velocidade a porcentagem de emergência de plântulas de sorgo-sudão são reduzidas a partir de 15 meses de armazenamento das sementes enquanto que a germinação, o desenvolvimento das plântulas e o peso são preservados até 18 meses. $\mathrm{O}$ armazenamento das sementes em ambiente natural ocasiona decréscimo no vigor mais rapidamente do que em câmara seca, geladeira e freezer, apesar do maior crescimento das plântulas nesta condição comparativamente às demais.

Palavras-chave: Sorghum sudanense; germinação; conservação; qualidade fisiológica. 
Cereal grains represent the main dietary source of protein/energy worldwide. Among those, sorghum is one of the most important cereal crops, being a major source of energy for livestock as well as millions of people (Ferreira et al., 2004). Currently, that species has been widely cropped in Brazilian central regions in off-season (Coelho et al., 2002) due to many beneficial attributes such as intermediate tolerance to drought (Tabosa et al., 2002) and saline stress (Tabosa et al., 2007).

Both organic and conventional farmers include sorghum species in rotation systems under no tillage management. Among them, sudangrass (Sorghum sudanense (Piper) Stapf) is known to produce large amounts of biomass, suppress weeds and decrease soil compaction.

Nevertheless, supply all cropping areas with seeds with high physiological, physical, genetic and sanitary quality in order to guarantee uniform and vigorous populations has yet been challenging (Carvalho et al., 2000). Seeds are one of the most important inputs in agriculture; among all production stages, storage is a mandatory concern, mainly in Brazilian subtropical and tropical conditions (Souza et al., 2009). According to Oliveira et al. (2011), studying behavior of seeds during storage, as well as biochemical changes and accumulation of secondary components, may bring relevant information to be applied in quality maintenance.

Quality attributes of seeds during storage are mostly influenced by relative humidity and air temperature. Relative humidity is closely related to variations in moisture content; conversely, temperature affects metabolic reactions, respiration, microorganism incidence and all deterioration processes as a consequence. According to Marcos
Filho (2005), low relative humidity and temperature are essential to maintain low activity levels and decrease reserve degradation. Dejene et al. (2004) found germination of sorghum grain from soil pit to decrease by $6 \%$ per storage month. That is the reason why Ahmed \& Alama (2010) have recommended storing sorghum seeds under either limited or fully controlled conditions, thus maintaining seed moisture, viability, germinability and field emergence close to that of newly harvested seed.

Although oil seeds have shown lower storage potential due to poor stability of lipids, it has also been problematic to store starchy seeds for extended periods, especially longer than the expected between growing seasons. Modifications in soluble-carbohydrate levels often limit the availability of reserve for respiration, therefore reducing seed germination and vigor (Marcos Filho, 2005). Maintaining moisture levels at $12-13 \%$, as recommended by Mantovani (2003), is also difficult in extended storage periods, as exchanging vapor between the seeds and the environment is constant due to hygroscopic properties.

Marcos Filho (2005) recommended maintaining moisture content between 8 and $10 \%$ for longer storage periods of six to eight months. Nevertheless, seeds of most grain crops such as corn, wheat, barley, oats and sorghum will maintain satisfactory germination and vigor for only about one year at moistures of $12-13 \%$ under environmental conditions of temperature. When longer storage is needed, seed moisture content should be less than $11 \%$ and the temperature should not exceed $20{ }^{\circ} \mathrm{C}$ (Copeland \& McDonald, 2001).

This study aimed to monitor physiological quality of sudangrass seeds stored under four environmental conditions for a period of 18 months. 


\section{Material and Methods}

This study was carried in College of Agricultural Sciences, Unesp, Botucatu, SP, Brazil (22 $2^{\circ} 49^{\prime} \mathrm{S}, 48^{\circ} 25^{\prime} \mathrm{W}$ and $770 \mathrm{~m}$ asl), with sudangrass seeds originally produced in Rio Grande do Sul State. Samples taken from a commercial seed lot were divided into four portions and stored in paper bags. Treatments consisted of maintaining each portion in a different environment, simulated by the following equipments: A - natural environment, with no control of relative humidity and temperature; B - dry chamber, with relative humidity of $30-40 \%$ and no temperature control; $\mathrm{C}$ - frost free, with $10-15 \%$ and $5-7{ }^{\circ} \mathrm{C}$ of relative humidity and temperature, respectively; D - freezer, with $40-50 \%$ and $-20{ }^{\circ} \mathrm{C}$ of relative humidity and temperature, respectively.

Physiological quality of seeds was assessed before storage and then every semester until 18 months by the following tests:

Water content: two subsamples per treatment were evaluated using an oven at $105 \pm 3$ ${ }^{\circ} \mathrm{C}$ for $24 \mathrm{~h}$ (wet basis); results were expressed as a percentage (Brasil, 2009).

Weight of 1,000 seeds: it was obtained by weighing eight subsamples of 100 seeds from each treatment. Results were multiplied by 10 and expressed in grams (Brasil, 2009).

Germination: four subsamples of 50 seeds per treatment were distributed on paper towels moistened with water equivalent to 2.5 the weight of the dry paper. Rolls were made and placed into plastic bags and left for germination at alternate temperature of 20 - $30^{\circ} \mathrm{C}$. Evaluation took place ten days after sowing (Brasil, 2009) and results were expressed as the mean percentage of normal seedlings.
First count of germination: it was performed along with the germination test; the percentage of normal seedlings was recorded on the fourth day after sowing (Brasil, 2009).

Electrical conductivity: four subsamples of 50 seeds per treatment were weighed and soaked into $200 \mathrm{ml}$ plastic cups containing $75 \mathrm{ml}$ of distilled water, for $24 \mathrm{~h}$ at $25{ }^{\circ} \mathrm{C}$ (Vieira \& Krzyzanowski, 1999); afterwards, the electrical conductivity $\left(\mu \mathrm{S} \mathrm{cm}^{-1}\right.$ $\mathrm{g}^{-1}$ ) of the solution was determined through reading in a conductivimeter.

Accelerated aging: as described by Marcos Filho (1999), 200 seeds per replication were arranged on accelerated aging trays and placed in plastic boxes $(11.0 \times 11.0 \times 3.5 \mathrm{~cm})$ containing $40 \mathrm{ml}$ of water at the bottom. The boxes were closed and placed inside plastic bags to minimize water loss. Afterwards, samples were kept inside specific equipment (Hitachi MT10) for accelerated aging at $43{ }^{\circ} \mathrm{C}$ for $72 \mathrm{~h}$. Right after this period, four subsamples of 50 seeds per replication were evaluated by the germination test as described previously. Evaluation took place four days after sowing (Brasil, 2009) and results were expressed as the mean percentage of normal seedlings. Moisture content was monitored after the aging period.

Seedling length: four replications of ten seeds per treatment were sown over a line drawn on paper towels moistened with water equivalent to 2.5 times the weight of the dry paper. Rolls were made and placed into plastic bags and left for germination in upright position at $25^{\circ} \mathrm{C}$ for 5 days (Nakagawa, 1999). Shoot, primary root and total length of seedlings were measured in $\mathrm{cm}$.

Seedling dry matter: normal seedlings of the seedling length test were placed into paper bags and dried using an oven at $80{ }^{\circ} \mathrm{C}$ for $24 \mathrm{~h}$. Results were obtained dividing each weight by the number of 
normal seedlings (Nakagawa, 1999). Then, the means were obtained for each treatment, in $\mathrm{mg}$.

Seedling emergence in field: four replications of 50 seeds were sown $3 \mathrm{~cm}$ deep in $2 \mathrm{~m}$ rows at 0.40 $\mathrm{m}$ spacing. Emergence of seedlings was expressed in percentage on the 14th day after sowing (Nakagawa, 1994).

Speed of emergence-index: the number of seedlings emerged in the field was recorded daily until the $14^{\text {th }}$ day after sowing; afterwards, data was applied to Maguire (1962)'s formula.

The experimental design was the completely randomized with four replications. Variance tests were applied for statistical analysis and means were compared as a $4 \times 4$ factorial (storage environment $\mathrm{x}$ storage time). Storage environments were compared by the Tukey test $(\mathrm{p} \leq 0.05)$ and storage time by regression analysis, choosing the significant equations with the higher coefficient of determination (R2). The software SISVAR ${ }^{\circledR}$ (Ferreira, 2011) was applied for statistical analysis.

\section{Results and Discussion}

Moisture content of sudangrass seeds found before storage (Table 1) can be considered appropriate for storage but not for an extended period (Marcos Filho, 2005; Copeland \& McDonald, 2001). Nevertheless, it was already expected that seed moisture would vary as they were stored in different environments especially as temperature and relative humidity conditions were distinct. Decreased moisture contents of seeds was found after a 18-month storage period under natural environment, frost free and freezer conditions in the first six months of storage. Seeds stored in freezer, representing relative humidity and temperature of $40-50 \%$ and $-20{ }^{\circ} \mathrm{C}$, respectively, showed high moisture content than seeds from other conditions. Storing seeds in frost free environment was efficient to maintain low moisture levels. That increased moisture content could be explained by the use of paper bags which absorb humidity, which agrees with Ferreira et al. (2010). According to Souza et al. (2009), moisture contents reported in seeds stored under natural conditions and in dry chamber decrease as storage time progresses.

Variance analysis of quality data showed significant effects of the interaction between storage environment and time on seed weight and vigor, evaluated by electrical conductivity and accelerated aging tests (Tables 2 and 3). On the other hand, seed germination and seedling dry matter were influenced

TABLE 1. Moisture content (\%) of sudangrass seeds affected by storage time and environment. Botucatu, SP, Brazil. ${ }^{1}$

\begin{tabular}{ccccc}
\hline \multirow{2}{*}{ Storage environment } & \multicolumn{4}{c}{ Storage time (months) } \\
\cline { 2 - 4 } & 0 & 6 & 12 & 18 \\
\hline A & 12.7 & 10.4 & 9.9 & 9.2 \\
B & 12.7 & 9.4 & 8.7 & 8.3 \\
C & 12.7 & 6.2 & 7.1 & 6.8 \\
D & 12.7 & 13.5 & 14.2 & 14.0
\end{tabular}

${ }^{1} \mathrm{~A}$ - environmental conditions; B - dry chamber; C - frost free; D - freezer. 
only by storage time, regardless any environments. At last, seedling development was affected by both storage environments and periods although no interaction was observed.

The equation adjusted to mean germination percentage showed slightly decrease in the beginning of storage. It is relevant to mention that germination was above the minimum value of $80 \%$ established for sorghum seeds to be acceptable (Brasil, 2005). Both percentage and speed of emergence in field revealed variable effects as storage time progress. According to fitting applied to mean data, seed vigor was reduced in the first six months of storage and was followed by an increase after that period; although a 15-month storage had seem to be the period when seed vigor is higher, values are still lower than the ones found before the conservation period. This behavior is often observed due to overcome seed dormancy (Marcos Filho, 2005).

According to this experiment, variations in germination and emergence may be due to overcoming dormancy, which naturally occurs during storage of sorghum seeds (Oliveira et al., 2011). Although storage environments did not differ from each other, those authors reported overcoming dormancy during conservation in cold chamber, which, in their work, was relevant when considering that seed germination began to increase from the 10th month. This period corresponded to June, when temperature and relative humidity are low, according to Köeppen's classification of Cwa dry cold winter in the region; therefore, even seeds stored under natural environment or in dry chamber, both with no control of temperature, may benefitted from those conditions. Studying pigeon pea seeds, Nakagawa et al. (2009) reported that dormant seeds affect germination during storage.

Seedling length was influenced by storage environment and time. Development of the primary root was improved with time, which reflected in increasing total length of sudangrass seedlings. Shoot length was initially decreased with time but was soon improved as storage progressed. Additionally, there may have been an improvement due to moisture uniformity, once initial values were not considered optimum for prolonged storage.

Storage environment significantly affected seed vigor evaluated by seedling measurements. It is already known that vigor reduction is often reported before germination losses can be detected (Marcos Filho, 2005). Storage of sudangrass seeds in dry chamber provided better conditions to preserve seed vigor, but not differing from conservation under natural environment and freezer; those were not different from seeds maintained in frost free, which produced shorter seedlings. Those results do not corroborate Nakagawa et al. (2004), who found that black oat seeds stored in frost free and freezer environments show better quality compared to conservation in dry chamber. On the other hand, Oliveira et al. (2011) found that cold temperatures during storage may increase seed dormancy. In any way, it is uncertain if dormancy is accentuated by cold-temperature storage or reducing of phenolic compounds. There are some studies about seed deterioration at $10{ }^{\circ} \mathrm{C}$ not being directly related to loss of membrane integrity (Fessel et al., 2006; Panobianco et al., 2007).

Influence of interactive effects of storage time and environment on seed weight was similar to isolate effects of storage periods on germination and emergence (Figure 1A). Storage environments seem to differ from each other in some periods, although seeds stored in the coldest temperature have constantly maintained higher weight compared to the other conditions. If all factors that influence storage potential of seeds are considered, it is noticeable that 
TABLE 2. Variance analysis of weight of 1,000 seeds (W, g), germination ( $\mathrm{G}, \%)$, seedling emergence in field (E, \%), speed of emergence-index (SEI), electrical conductivity (EC, $\mu \mathrm{S} \mathrm{cm}^{-1} \mathrm{~g}^{-1}$ ) and accelerated aging (AA, $\%$ ) of sudangrass affected by seed storage time and environment. Botucatu, SP, Brazil.

\begin{tabular}{|c|c|c|c|c|c|c|c|}
\hline \multirow{2}{*}{\multicolumn{2}{|c|}{ Variation sources }} & \multicolumn{6}{|c|}{ Evaluations } \\
\hline & & $\mathrm{W}$ & $\mathrm{G}$ & $\mathrm{E}$ & SEI & $\mathrm{EC}$ & $\mathrm{AA}$ \\
\hline \multirow{5}{*}{$\begin{array}{l}\text { Storage time } \\
\text { (months) }\end{array}$} & 0 & 0.94 & 91 & 84 & 2.67 & 24.83 & 84 \\
\hline & 6 & 0.92 & 88 & 52 & 3.82 & 31.38 & 81 \\
\hline & 12 & 0.90 & 87 & 68 & 6.97 & 32.17 & 78 \\
\hline & 18 & 1.06 & 89 & 65 & 5.97 & 37.69 & 77 \\
\hline & Regression & - & $\mathrm{Q}^{2}$ & $\mathrm{C}^{3}$ & $\mathrm{C}^{4}$ & - & - \\
\hline \multirow{4}{*}{$\begin{array}{c}\text { Storage } \\
\text { environment }^{1}\end{array}$} & A & 0.95 & 88 & 67 & 4.79 & 33.13 & 77 \\
\hline & B & 0.95 & 91 & 68 & 5.00 & 32.02 & 82 \\
\hline & $\mathrm{C}$ & 0.94 & 88 & 69 & 4.91 & 31.48 & 81 \\
\hline & $\mathrm{D}$ & 0.98 & 87 & 65 & 4.73 & 29.42 & 80 \\
\hline \multicolumn{2}{|c|}{ Interaction } & $1.987^{*}$ & $0.871^{\mathrm{ns}}$ & $1.194^{\mathrm{ns}}$ & $0.660^{\mathrm{ns}}$ & $2.123^{*}$ & $2.497^{*}$ \\
\hline \multicolumn{2}{|c|}{ CV (\%) } & 3.79 & 3.95 & 11.44 & 20.38 & 8.76 & 7.64 \\
\hline
\end{tabular}

${ }^{1} \mathrm{~A}$ - environmental conditions; B - dry chamber; C - frost free; D - freezer. ${ }^{2} \mathrm{y}=0.03 \mathrm{x}^{2}-0.74 \mathrm{x}+91.05 \mathrm{R}^{2}=0.99^{* *}$; ${ }^{3} \mathrm{y}=-0.05 \mathrm{x}^{3}+1.60 \mathrm{x}^{2}-13.06 \mathrm{x}+84 \mathrm{R}^{2}=1^{* *} ;{ }^{4} \mathrm{y}=-0.00 \mathrm{x}^{3}+0.11 \mathrm{x}^{2}-0.32 \mathrm{x}+2.67 \mathrm{R}^{2}=1^{* *}$. ${ }^{*}$ significant $(\mathrm{p}<0,05)$; ${ }^{\mathrm{n}}$ not significant.

TABLE 3. Variance analysis of root length (RL, $\mathrm{cm})$, shoot length (SL, $\mathrm{cm})$, seedling total length $(\mathrm{TL}, \mathrm{cm})$ and seedling dry matter (DM, mg) of sudangrass affected by seed storage time and environment. Botucatu, SP, Brazil. ${ }^{1}$

\begin{tabular}{|c|c|c|c|c|c|}
\hline \multirow{2}{*}{\multicolumn{2}{|c|}{ Variation sources }} & \multicolumn{4}{|c|}{ Evaluations } \\
\hline & & $\mathrm{RL}$ & $\mathrm{SL}$ & $\mathrm{TL}$ & $\mathrm{DM}$ \\
\hline \multirow{5}{*}{$\begin{array}{l}\text { Storage time } \\
\text { (months) }\end{array}$} & 0 & 4.13 & 5.08 & 9.25 & 3.43 \\
\hline & 6 & 6.87 & 3.98 & 10.88 & 3.07 \\
\hline & 12 & 8.37 & 4.84 & 13.31 & 3.35 \\
\hline & 18 & 8.56 & 7.97 & 16.63 & 4.11 \\
\hline & Regression & $\mathrm{Q}^{2}$ & $\mathrm{Q}^{3}$ & $\mathrm{~L}^{4}$ & $\mathrm{Q}^{5}$ \\
\hline \multirow{4}{*}{$\begin{array}{c}\text { Storage } \\
\text { environment }^{6}\end{array}$} & A & $7.19 \mathrm{ab}$ & $5.90 \mathrm{ab}$ & $13.13 \mathrm{ab}$ & 3.49 \\
\hline & $\mathrm{B}$ & $7.88 \mathrm{a}$ & $5.99 \mathrm{a}$ & $13.94 \mathrm{a}$ & 3.44 \\
\hline & $\mathrm{C}$ & $6.26 \mathrm{~b}$ & $4.97 \mathrm{~b}$ & $11.31 \mathrm{~b}$ & 3.50 \\
\hline & $\mathrm{D}$ & $6.59 \mathrm{ab}$ & $5.00 \mathrm{ab}$ & $11.69 \mathrm{ab}$ & 3.53 \\
\hline \multicolumn{2}{|c|}{ Interaction } & $1.409^{\mathrm{ns}}$ & $1.538^{\mathrm{ns}}$ & $1.505^{\mathrm{ns}}$ & $1.433^{\mathrm{ns}}$ \\
\hline \multicolumn{2}{|c|}{$\mathrm{CV}(\%)$} & 23.26 & 19.60 & 20.05 & 15.44 \\
\hline
\end{tabular}

${ }^{1}$ Means followed by the same letter in the column to compare storage environments do not differ significantly by the Tukey test $(p \geq 0.05) .{ }^{2} y=-0.02 x^{2}+0.57 x+4.13 ; R^{2}=1{ }^{* *} ;{ }^{3} y=0.03 x^{2}-0.37 x+5.10 ; R^{2}=0.99^{* *} ;{ }^{4} y=0.41 x+$ $8.83 ; \mathrm{R}^{2}=0.98^{* *} ; 5 \mathrm{y}=0.01 \mathrm{x}^{2}-0.10 \mathrm{x}+3.42 ; \mathrm{R}^{2}=0.99^{* *} .{ }^{6} \mathrm{~A}$ - environmental conditions; $\mathrm{B}$ - dry chamber; $\mathrm{C}$ - frost

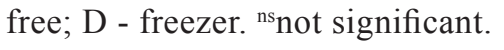



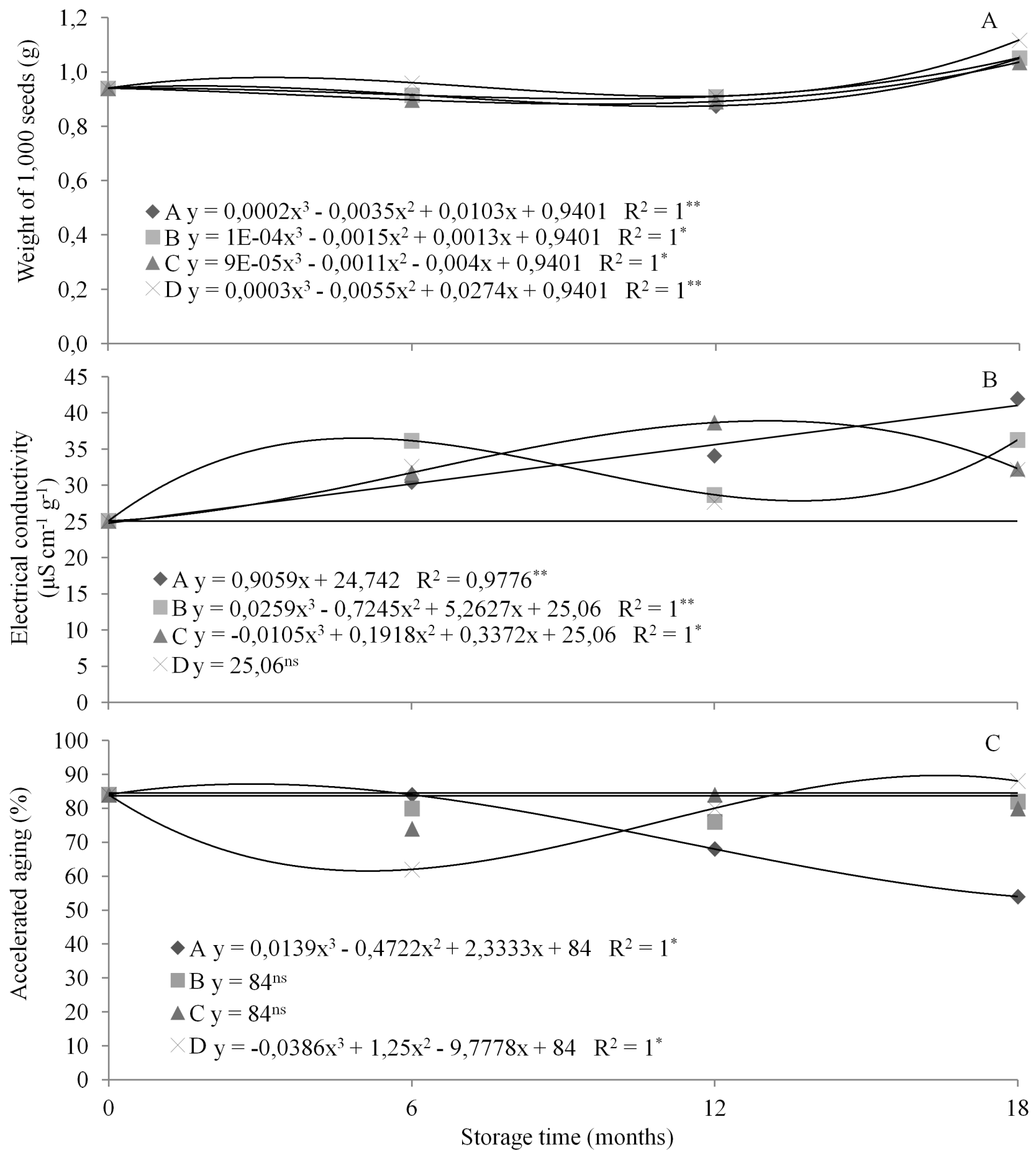

FIGURE 1. Weight of 1,000 seeds (A), electrical conductivity (B) and accelerated aging (C) of sudangrass seeds affected by storage time and environment. Botucatu, SP, Brazil. $\downarrow$ A - environmental conditions; $\square \mathrm{B}$ - dry chamber; $\boldsymbol{\Delta} \mathrm{C}$ - frost free; $\times \mathrm{D}$ - freezer. LSD - least significant difference. ${ }^{*}$ and ${ }^{* *}$ significant at a probability

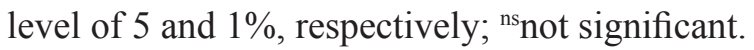


seed moisture in freezer was higher; however, more favorable conditions of temperature can be attributed to that environment, as sudangrass seeds are classified as orthodox (Marcos Filho, 2005).

Electrical conductivity and accelerated aging showed consistent behavior of sudangrass seeds stored under natural environment conditions (Figure 1B and 1C). In that case, higher conductivity values and lower germination after aging were found after the 18th month. In this experiment, effects of storage time and environment were significantly detected at least by one of the tests, which disagree with Soares et al. (2010), who concluded that the accelerated aging test is efficient to classify seed lots in vigor levels whereas conductivity evaluations are not efficient but only identify low-vigor lots. Electrical conductivity values were significantly correlated to moisture content variations during storage $\left(r=-0.56^{*}\right)$.

Starch is the main component of sudangrass seeds (Marcos Filho, 2005); therefore, those show greater storage potential than oil seeds. Under natural environment conditions, moisture content may vary depending on oscillations in relative humidity and, along with temperature variations, can determine deterioration rates in seeds and physiological quality losses. According to Toledo et al. (2007), in the first stage of this study, storage of sudangrass seeds in frost free e freezer environments improves physiological quality. Similarly, Nakagawa et al. (2004) found that maintaining seeds in frost free and freezer conditions can preserve physiological quality of black oat seeds compared to storage in dry chamber. However, it is possible those environment conditions become inappropriate to preserve quality as storage time progresses and deleterious effects of low temperature begin to take place.

\section{Conclusions}

Speed and percentage of seedling emergence are reduced after 15-month storage of sudangrass seeds whereas seed germination, seedling development and seed weight are preserved until 18 months.

Storing seeds under natural environment decrease vigor faster than conservation in dry chamber, frost free and freezer, although seedling growth is still increased in that condition compared to the others.

\section{Acknowledgements}

To São Paulo State University (Unesp PIBIC/REITORIA) for providing scholarship to the first author.

\section{References}

AHMED, E. E. A.; ALAMA, S. H. A. Sorghum (Sorghum bicolor (L.) Moench.) seed quality as affected by type and duration of storage. Agriculture and Biology Journal of North America, Milford, v. 1, n. 1, p. 1-8, 2010.

BRASIL. Ministério da Agricultura, Pecuária e Abastecimento. Padrões para a produção e comercialização de sementes de sorgo granífero e forrageiro. Anexo X. Instrução normativa $\mathrm{n}^{\circ} 25$ de 16 de dezembro de 2005 .

Diário Oficial da União, Brasília, DF, $\mathrm{n}^{\circ}$ 243, Seção 1, 20/12/2005. p. 24-25.

BRASIL. Ministério da Agricultura, Pecuária e Abastecimento. Regras para análise de sementes. Brasília, DF: MAPA/ACS, 2009. $399 \mathrm{p}$.

CARVALHO, L. F.; MEDEIROS-FILHO, S.; 
ROSSETTI, A. G.; TEÓFILO, E. M. Condicionamento osmótico em sementes de sorgo. Revista Brasileira de Sementes, Londrina, v. 22, n. 1, p. 185-192, 2000.

COELHO, A. M.; WAQUIL, J. M.; KARAN, D.; CASELA, C. R.; RIBAS, P. M. Seja o doutor do seu sorgo. Piracicaba: POTAFOS, 2002. 24 p. il. (Arquivo do Agrônomo, 14). Encarte do Informações Agronômicas, n. 100, 2002. COPELAND, L. O.; McDONALD, M. F. Principles of seed science and technology. 4. ed. New York: Chapman and Hall, 2001. 488 p.

DEJENE, M.; YUEN, J.; SIGVALD, R. The impact of storage methods on storage environment and sorghum grain quality. Seed Science and Technology, Zürich, v. 32, p. 511-529, 2004.

FERREIRA, D. F. Sisvar: a computer statistical analysis system. Ciência e Agrotecnologia, Lavras, v. 35, n. 6, p. 1039-1042, 2011.

FERREIRA, E. G. B. S.; MATOS, V. P.; FERREIRA, R. L. C.; SALES, A. G. F. A.; SENA, L. H. M. Vigor das sementes de Apeiba tibourbou Aubl. Sob diferentes condições de armazenamento e embalagens.

Ciência Florestal, Santa Maria, v. 20, n. 2, p. 295-305, 2010.

FERREIRA， R. R.; VENDEMIATTI, A.; MEINHARDT, L. W.; LEA, P. J.; AZEVEDO, R. A. Isolation of enzymes involved in threonine biosynthesis from sorghum seeds. Brazilian Journal of Plant Physiology, Campos dos Goytacazes, v. 16, n. 2, p. 95104, 2004.

FESSEL, S. A.; VIEIRA, R. D.; CRUZ, M. C. P.; PAULA, R. C.; PANOBIANCO, M. Electrical conductivity testing of corn seeds as influenced by temperature and period of storage. Pesquisa Agropecuária Brasileira, Brasília, DF, v. 41, n. 10, p. 1551-1559, 2006.

MAGUIRE, J. D. Speed of germination-aid in relation evaluation for seedling emergence vigor. Crop Science, Madison, v. 2, n. 2, p. 176-177, 1962.

MANTOVANI, E. C. Plantio e colheita de sorgo. Sete Lagoas: Embrapa Milho e Sorgo, 2003. 6 p. (Embrapa Milho e Sorgo. Comunicado técnico, 75).

MARCOS FILHO, J. Fisiologia de sementes de plantas cultivadas. Piracicaba: FEALQ, 2005. 495 p.

MARCOS FILHO, J. Teste de envelhecimento acelerado. In: KRZYZANOWSKI, F. C.; VIEIRA, R. D.; FRANÇA-NETO, J. B. (Ed.). Vigor de sementes: conceitos e testes. Londrina: ABRATES, 1999. p. 150-168.

NAKAGAWA, J. Testes de vigor baseados na avaliação das plântulas. In: VIEIRA, R. D.; CARVALHO, N. M. (Ed.). Testes de vigor em sementes. Jaboticabal: FUNEP, 1994. p. 49-85.

NAKAGAWA, J. Testes de vigor baseados no desempenho das plântulas. In: KRZYZANOWSKI， F. C.; VIEIRA， R. D.; FRANÇA NETO, J. B. (Ed.). Vigor de sementes: conceitos e testes. Londrina: ABRATES, 1999. cap. 2, p. 2-24.

NAKAGAWA, J.; CAVARIANI, C.; CASTRO, M. M. Armazenamento de sementes de aveia-preta produzidas em solos de diferentes fertilidades. Revista Brasileira de Sementes, Londrina, v. 26, n. 2, p. 7-14, 2004.

NAKAGAWA, J.; CAVARIANI, C.; TOLEDO, M. 
Z. Germinação de sementes armazenadas de guandu. Revista Brasileira de Sementes, Londrina, v. 31, n. 4, p. 43-49, 2009.

OLIVEIRA, J. A.; SILVA, T. T. A.; VON PINHO, E. V. R.; ABREU, L. A. S. Secagem e armazenamento de sementes de sorgo com alto e baixo teor de tanino. Revista Brasileira de Sementes, Londrina, v. 33, n. 4, p. 699-710, 2011.

PANOBIANCO, M.; VIEIRA, R. D.; PERECIN, D. Electrical conductivity as an indicator of pea seed aging of stored at different temperatures. Scientia Agricola, Piracicaba, v. 64, p. 119-124, 2007.

SOARES, M. M.; CONCEIÇÃO, P. M.; DIAS, D. C. F. S.; ALVARENGA, E. M. Testes para avaliação do vigor de sementes de sorgo com ênfase à condutividade elétrica. Ciência e Agrotecnologia, Lavras, v. 34, n. 2, p. 391397, 2010.

SOUZA, G. F. M. V.; SANTOS, C. M.; SANTANA, D. G.; SÁ JÚNIOR, A. Armazenamento de sementes de sorgo submetidas a diferentes graus de umidade na colheita. Semina: Ciências Agrárias, Londrina, v. 30, n. 4, p. 745-752, 2009.

TABOSA, J. N.; COLAÇO, W.; REIS, O. V.; SIMPLÍCIO, J. B.; CARVALHO, H. W. L.;
DIAS, F. M. Sorghum genotypes evaluation under salinity levels and gamma ray. Revista Brasileira de Milho e Sorgo, Sete Lagoas, v. 6, n. 3, p. 339-350, 2007.

TABOSA, J. N.; REIS, O. V.; BRITO, A. R. M. B.; MONTEIRO, M. C. D.; SIMPLÍCIO, J. B.; OLIVEIRA, J.A.C.; SILVA, F. G.;AZEVEDO NETO, A. D.; DIAS, F. M.; LIRA, M. A.; TAVARES FILHO, J. J.; NASCIMENTO, M. M. A.; LIMA, L. E.; CARVALHO, H. W. L.; OLIVEIRA, L. R. Comportamento de cultivares de sorgo forrageiro em diferentes ambientes agroecológicos dos Estados de Pernambuco e Alagoas. Revista Brasileira de Milho e Sorgo, Sete Lagoas, v. 1, n. 2. p. 47-58, 2002.

TOLEDO, M. Z.; CAVARIANI, C.; NAKAGAWA, J.; ALVES, E. Efeitos do ambiente de armazenamento na qualidade de sementes de sorgo-sudão. Revista Brasileira de Sementes, Londrina, v. 29, n. 2, p. 44-52, 2007.

VIEIRA, R. D.; KRZYZANOWSKI, F. C. Teste de condutividade elétrica. In: KRZYZANOWSKI, F. C.; VIEIRA, R. D.; FRANÇA NETO, J. B. (Ed.). Vigor de sementes: conceitos e testes. Londrina: ABRATES, 1999. p. 1-26. 